\title{
Author Correction: Understanding the genetic determinants of the brain with MOSTest
}

\author{
Dennis van der Meer (D), Oleksandr Frei (D), Tobias Kaufmann (D), Alexey A. Shadrin, Anna Devor (D, \\ Olav B. Smeland (D), Wesley K. Thompson, Chun Chieh Fan (1), Dominic Holland, Lars T. Westlye (D), \\ Ole A. Andreassen (1) \& Anders M. Dale
}

Correction to: Nature Communications https://doi.org/10.1038/s41467-020-17368-1, published online 14 July 2020.

The original version of the Supplementary information associated with this Article contained errors in Supplementary Figs. 2A, 3A, 4A, 5B, 7A, 7B, and 9. The HTML has been updated to include a corrected version of the Supplementary information; the original incorrect versions of these figures can be found as Supplementary information associated with this Correction.

Published online: 14 September 2020

\begin{abstract}
(c) (i) Open Access This article is licensed under a Creative Commons Attribution 4.0 International License, which permits use, sharing, adaptation, distribution and reproduction in any medium or format, as long as you give appropriate credit to the original author(s) and the source, provide a link to the Creative Commons license, and indicate if changes were made. The images or other third party material in this article are included in the article's Creative Commons license, unless indicated otherwise in a credit line to the material. If material is not included in the article's Creative Commons license and your intended use is not permitted by statutory regulation or exceeds the permitted use, you will need to obtain permission directly from the copyright holder. To view a copy of this license, visit http://creativecommons.org/licenses/by/4.0/.
\end{abstract}

(C) The Author(s) 2020 